\title{
Four-dimensional growth response of mature Larix decidua to stem burial under natural conditions
}

\author{
Barbara Kogelnig-Mayer • Markus Stoffel • \\ Michelle Schneuwly-Bollschweiler
}

Received: 12 February 2013/Accepted: 21 February 2013/Published online: 7 March 2013

(C) Springer-Verlag Berlin Heidelberg 2013

\begin{abstract}
This paper illustrates the effects of abrupt stem burial (burial depth $\sim 0.5 \mathrm{~m}$ ) on tree growth in mature (46 \pm 8 years) European larch (Larix decidua Mill.) trees. In contrast to the previous research, which was mostly carried out with saplings and on experimental sites where regular aggradation occurred through the transport of sand, this work focuses on the impact of natural, abrupt burial of mature trees with rocks contained in a sandy-silty matrix typical for debris flows in mountainous headwater catchments. The effect of burial is assessed radially and axially within the stem and over almost three decades after burial. The analysis of growth disturbances and their intensity was based on the 143 cross sections ( 572 growth series) taken at 10-cm intervals from 6 Larix decidua Mill. The results show quite clearly that abrupt burial causes massive suppression of radial growth as compared to pre-event conditions (mean $77 \%, \min 38 \%$, $\max 92 \%$, SD $7.2 \%$ ). The trees sampled were unable to resume pre-burial growth rates even after 25 years, but recovered to reference growth
\end{abstract}

Communicated by L. Gratani.

B. Kogelnig-Mayer

Institute of Mountain Risk Engineering, University of Natural Resources and Applied Life Sciences, Peter Jordanstrasse 82, 1190 Vienna, Austria

\section{Stoffel · M. Schneuwly-Bollschweiler}

Laboratory of Dendrogeomorphology, Institute of Geological

Sciences, University of Berne, Baltzerstrasse 1+3,

3012 Berne, Switzerland

\section{Stoffel ( $\square)$}

Climate Change and Climatic Impacts, Environmental Sciences, University of Geneva, 7 chemin de Drize,

1227 Carouge-Geneva, Switzerland

e-mail: markus.stoffel@dendrolab.ch conditions (as measured in undisturbed, local reference trees) after 15 years (min 3 years, max 25 years, SD 9 years). The results differ only insignificantly between different heights along the tree axis and suppression is equally well expressed at different radial positions within the stem.

Keywords Growth suppression - Stem burial · Larix decidua (Mill.) · Growth response · Natural conditions . Debris flow

\section{Introduction}

Burial of plants, beyond their threshold level of tolerance, results in abiotic stresses and may filter intolerant species out of the community (Maun 2004; Dech and Maun 2006). Reactions of herbaceous and woody plants have been studied extensively in sand dune environments, where burial typically occurs as high frequency-low magnitude events through saltation (Kent et al. 2001). Most work in sandy environments focused on burial tolerance and adaptive traits (e.g., adventitious root formation, plastic resource allocation to biomass, rapid vertical elongation of shoots) in saplings of woody plants (e.g., Zhang and Maun 1990; Singh and Rathod 2002; Shi et al. 2004; Dech and Maun 2006; Liu et al. 2007; Zhao et al. 2007).

In contrast to the large body of experimental studies focusing on burial effects in sapling, relatively not much work has been performed on mature trees. Early work on mature plants has demonstrated that stem burial is likely to result in pronounced narrowing of radial growth as the most frequent and obvious reaction to burial, at least in gymnosperms (e.g., Hupp 1988; Rubtsov and Salmina 1983; Friedman et al. 2005). This abrupt growth reduction 
is reflecting the reduced root activity and mechanical effects of the enormous weight of debris (Kny 1877; Rubner 1919). The pressure of deposited material to the cambium hinders cell division and leads to reduced cell numbers. Sand burial has, in addition, been reported to result in root-like tracheids with increased size of individual cells (e.g., Nanson and Beach 1977; Shroder 1978; Cournoyer and Filion 1994; Friedman et al. 2005; Stoffel et al. in press). Dech (2004) noted that the accretion of sand $(\leq 1 \mathrm{~m})$ will result in increased bulk density and soil moisture as well as in a decrease in soil temperature. These changes will reduce aeration in the original root soil, and subsequently hamper access to water and nutrients (Yoshihika and Hukusima 1997; Maun 1998; Jury and Horton 2004; Matisons and Brümelis 2008; Day et al. 2001). Strunk (1991) reported that mature and old-growth Picea abies (L.) Karst. trees were able to survive multiple burial events of up to $1.7 \mathrm{~m}$ in dolomitic depositional environments and capable of forming several levels of adventitious roots.

Previous work provided valuable insight into variations in the response of saplings and mature wood plants to burial in sandy environments, but also points to the clear need for more research on the spatial and temporal effect of sudden burial of mature trees to bridge a significant gap in knowledge of the ecology of riparian environments. The objectives of this study therefore were to analyze the consequences of abrupt burial of Larix decidua Mill. trees by a debris flow in 1979. The specific aims of this study were (1) to document the growth response of $L$. decidua trees to stem burial and (2) to assess the spatial and temporal distribution of tree-ring widths in the stem. The study is based on the 143 cross sections (572 measured growthring series) obtained from six mature ( $46 \pm 8$ years) L. decidua trees from a debris-flow channel in the southern Swiss Alps.

\section{Materials and methods}

\section{Study site}

This study was performed along the channel of the Feergraben, southern Swiss Alps $\left(46^{\circ} 11^{\prime} \mathrm{N}, 8^{\circ} 05^{\prime} \mathrm{E} ; 1,230 \mathrm{~m}\right.$ a.s.l.) where a debris flow has buried $L$. decidua trees with $\sim 0.5 \mathrm{~m}$ of gneiss and schist boulders (Bearth 1973) contained in a sandy-silty matrix in late 1979. Other disturbances by debris flows occurred in 2001 and 2005, and might have enhanced some of growth reactions (Table 1). Signs of other disturbances are clearly missing at the study site. Climate at the study site is continental with mean annual air temperature of $\sim 5{ }^{\circ} \mathrm{C}$ (coldest month $-2.9{ }^{\circ} \mathrm{C}$, warmest month $13.4{ }^{\circ} \mathrm{C}$ ) and mean annual precipitation of
Table 1 Tree age, tree height $(\mathrm{m})$, diameter at breast height (DBC, in $\mathrm{cm}$ ) and number of cross sections of $L$. decidua trees

\begin{tabular}{lllllll}
\hline Tree no. & I & II & III & IV & V & VI \\
\hline Age & 47 & 54 & 43 & 42 & 43 & 47 \\
Tree height (m) & 16 & 14 & 13 & 13 & 5 & 12 \\
DBH (cm) & 14.9 & 14.3 & 21.0 & 16.5 & 7.6 & 23.8 \\
$\quad$ No. of cross & 18 & 30 & 16 & 24 & 31 & 24 \\
$\quad$ sections & & & & & & \\
$\quad \begin{array}{l}\text { Growth } \\
\quad \text { suppression }\end{array}$ & 1979 & 1979, & 1979 & 1979 & 1979 & 1979 \\
$\quad \begin{array}{c}\text { Injuries } \\
\quad 2001,\end{array}$ & 2001, & 2001 & 2001 & 2001 & \\
& 2005 & 2005 & & & & \\
\hline
\end{tabular}

1,216 mm (MeteoSwiss 2008). Local phenological data indicate that the vegetation period lasts from mid-May to mid-October (Müller 1980).

Sampling and data analysis

Debris flows are fast moving mixtures of water and debris carrying material ranging in size from clay to boulders (up to several meters in diameter). Burial of trees with debrisflow material is supposed to have severe and prolonged impacts on tree growth (Stoffel et al. 2005, 2008), but experimental work on this topic has yet to be realized.

The sampling of trees for this study was performed in summer 2005. Based on an outer inspection of their trunks, we selected six $L$. decidua trees with buried stem bases. Trees were excavated to the root level (which was at $\sim 0.5$ below the current ground level) and sampled with a chain saw. Cross sections were taken every $10 \mathrm{~cm}$ in general, but individual sampling heights have been adapted occasionally to avoid branches or roots. In addition, samples from 28 undisturbed $L$. decidua growing next of the study site have been collected to build a reference chronology. Two cores per tree were extracted in this case, with samples taken at breast height. Cores and cross sections were prepared following standard dendrogeomorphic procedures as described in Stoffel and Bollschweiler (2008, 2009).

In the laboratory, we first analyzed growth disturbances visually in the tree-ring series and excluded samples with responses other than those typical for burial (such as compression wood, injuries or callus tissue). Ring widths were then measured on four different sides for each cross section (Fig. 1), with $c$ representing the upslope side with respect to the flow direction of the debris flow. We used a digital LINTAB positioning table connected to a Leica stereomicroscope and TSAP-Win Scientific 4.63 software (Rinntech 2011) for the measurements.

For the reference samples, ring widths were measured for each sample and the growth curves of each reference tree averaged and indexed. The mean growth curves of all 


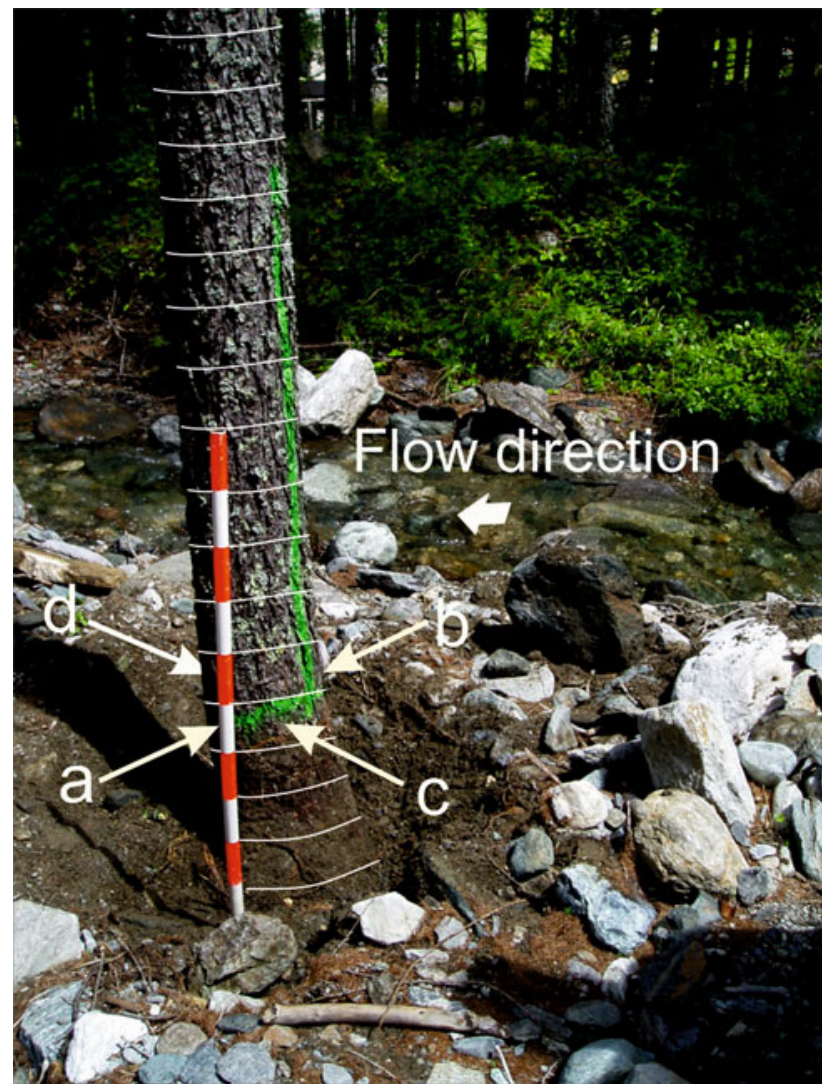

Fig. 1 Six Larix decidua Mill. trees with buried stem bases were excavated and felled into $10 \mathrm{~cm}$ pieces with a chain saw. After sanding, each cross section was measured from four different sides $(a, b, c, d)$

trees were then summarized to form a reference chronology representing normal growth patterns of $L$. decidua at the study site. The impact of stem burial on radial growth was assessed by comparing reference growth with that measured in the buried trees. The analysis of growth suppression in the stem following burial by the 1979 debris flow was performed in the radial and axial directions and was quantified as follows:

Growth suppression (in \%) $=100$

$-\left(\frac{\text { total growth in first year or suppression }[\mu \mathrm{m}] \times 100}{\text { total growth in year before suppression }[\mu \mathrm{m}]}\right)$

The axial distribution of growth suppression was assessed based on the mean tree-ring widths as measured for individual cross sections, and performed by linear regression. Linear relationship was tested with a $t$ test $(p<0.05)$. The influence of sampling position $(a, b, c$, or $d)$ on growth suppression (i.e., radial distribution of growth suppression; in \%) was determined using the analysis of variance (ANOVA; significance level $p<0.05$ ).

\section{Results}

General description of disturbed trees

Table 1 provides data on tree age (at $10 \mathrm{~cm}$ above original ground level, at ca. $-40 \mathrm{~cm}$ ), diameter at breast height $(\mathrm{DBH})$, and number of cross sections per tree. The oldest tree selected for analysis was 54 years old when felled, whereas 42 growth rings were counted in the youngest tree. Tree height ranged from $5 \mathrm{~m}$ (tree V) to $16 \mathrm{~m}$ (tree I). All trees showed clear growth suppression as a result of stem burial in late 1979, and most had injuries and subsequent tangential rows of traumatic resin ducts (Bollschweiler et al. 2008) reflecting the impact of debris flows and associated cambium damage in 2001 and 2005, but were not affected by additional burial ever since the occurrence of the debris flows and related deposition of material in late 1979.

Stem burial, persistence of and recovery from growth suppression

The abrupt decrease in tree-ring width (overall and as compared to the reference chronology) in 1980 as a result of sudden stem burial with debris-flow material in late 1979 is illustrated in Fig. 2. Although tree growth before burial was in all cases higher than growth in reference trees-certainly because of the younger tree age of buried as compared to reference trees-all buried $L$. decidua trees exhibited a sharp and abrupt decrease in ring width starting in 1980 and lasting for 14 years on average (SD 9 years). Following burial, radial growth rates remained very low in trees II and V with annual increments ranging between 10 and $70 \mu \mathrm{m}$ (mean annual growth of 33 and $25 \mu \mathrm{m}$ year $^{-1}$ for trees II and V, respectively). Tree IV performed best after burial and attained normal growth rates within 3 years after disturbance.

\section{Quantifying growth suppression after burial}

Between 1969 and 1979, mean annual tree-ring widths varied between $154.9 \mu \mathrm{m}$ (tree I) and $222.2 \mu \mathrm{m}$ (tree V). In the first 3 years after burial (i.e., 1980-1982), mean annual growth was reduced by at least $61 \%$ (tree III) and up to $83 \%$ (tree VI) when compared with pre-burial increment rates. The range of relative changes (in \%) in ring width before and after burial is summarized in Fig. 3 and contains data from all cross sections taken per tree at $10-\mathrm{cm}$ intervals. With the exception of tree $\mathrm{V}$, all trees a small interquartile ranges, indicating that changes in ring width do not differ significantly between the different locations on a cross section and between cross sections within the same tree. 
Fig. 2 Comparison of the reference chronology (dashed line) with the different mean growth curves of the sampled trees (solid line). The time span of growth suppression after stem burial is delighted in grey

Fig. 3 Boxplot summarizing reductions in ring width following burial (in \%) as compared to pre-burial (1969-1979) growth rates for each of the trees sampled
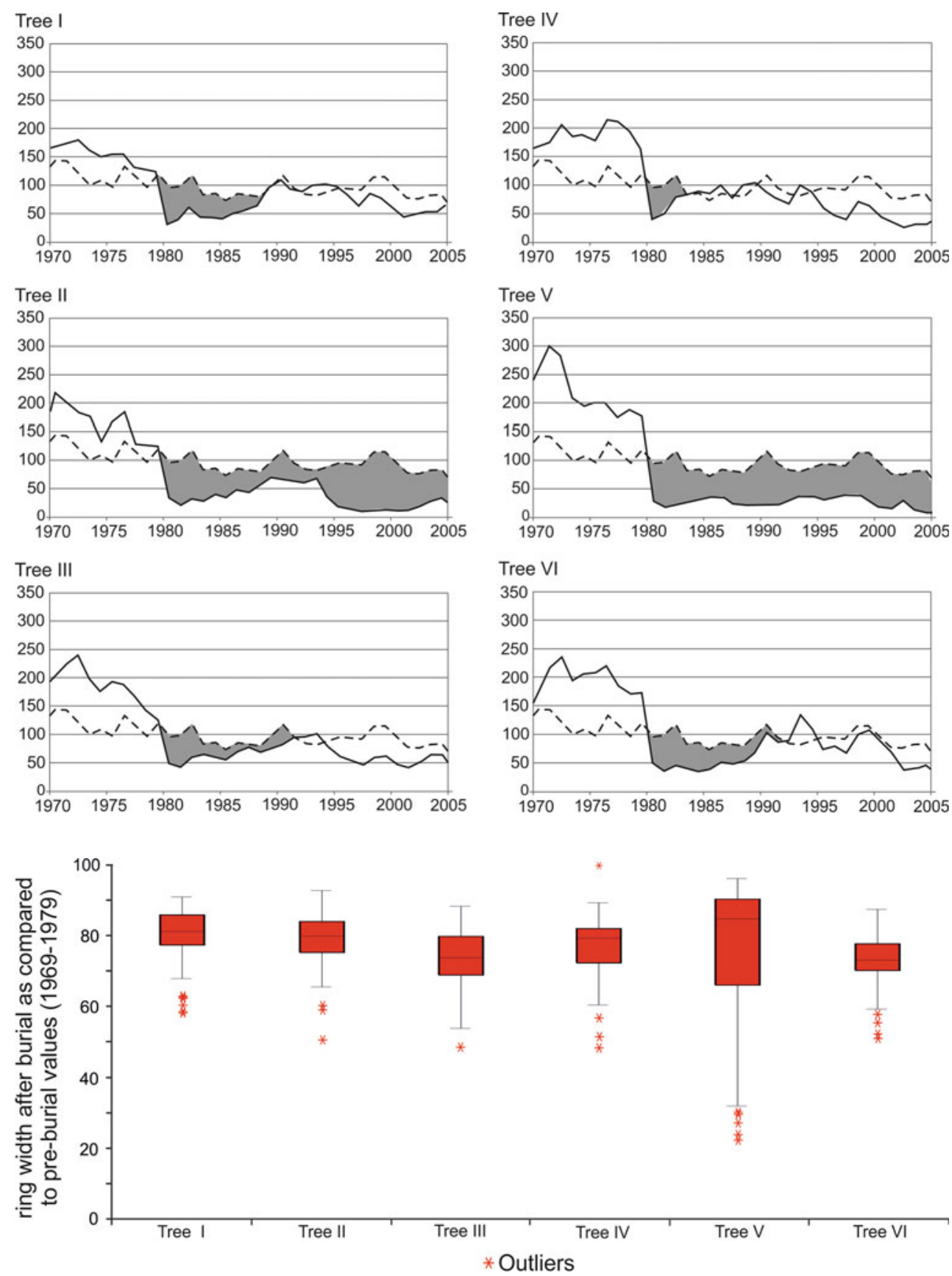

Axial distribution of growth suppression

Relative changes in growth suppression in the axial direction are shown in Fig. 4 for $10 \mathrm{~cm}$ steps of the first 1.5-3 $\mathrm{m}$ of the trunks. The severity of the growth reduction remained mostly comparable within a tree and varied by a maximum of $45.1 \%$ (tree $\mathrm{V}$; $\max 91.6 \%$ at $1.4 \mathrm{~m}$, min $46.5 \%$ at $0.1 \mathrm{~m})$. The smallest differences were observed in tree VI where they accounted for $14.7 \%$ (i.e., growth reduced by $81.3 \%$ at $1.8 \mathrm{~m}$ as compared to $66.5 \%$ at $1.1 \mathrm{~m})$. Based on our data, there is no clear tendency for growth reductions to be more (less) important at a specific height and linear regressions point to either slightly positive or negative, but insignificant trends with increasing sampling height. Tree $\mathrm{V}$ is different from the others in the sense that the smallest growth decrease when compared with pre-burial growth is observed close to the root collar and above $2.5 \mathrm{~m}$.

Radial distribution of growth suppression

The radial distribution of growth suppression was analyzed for each of the 143 cross sections, for which a total of 572 series was measured on sides $a, b, c$, and $d$ (for details see 


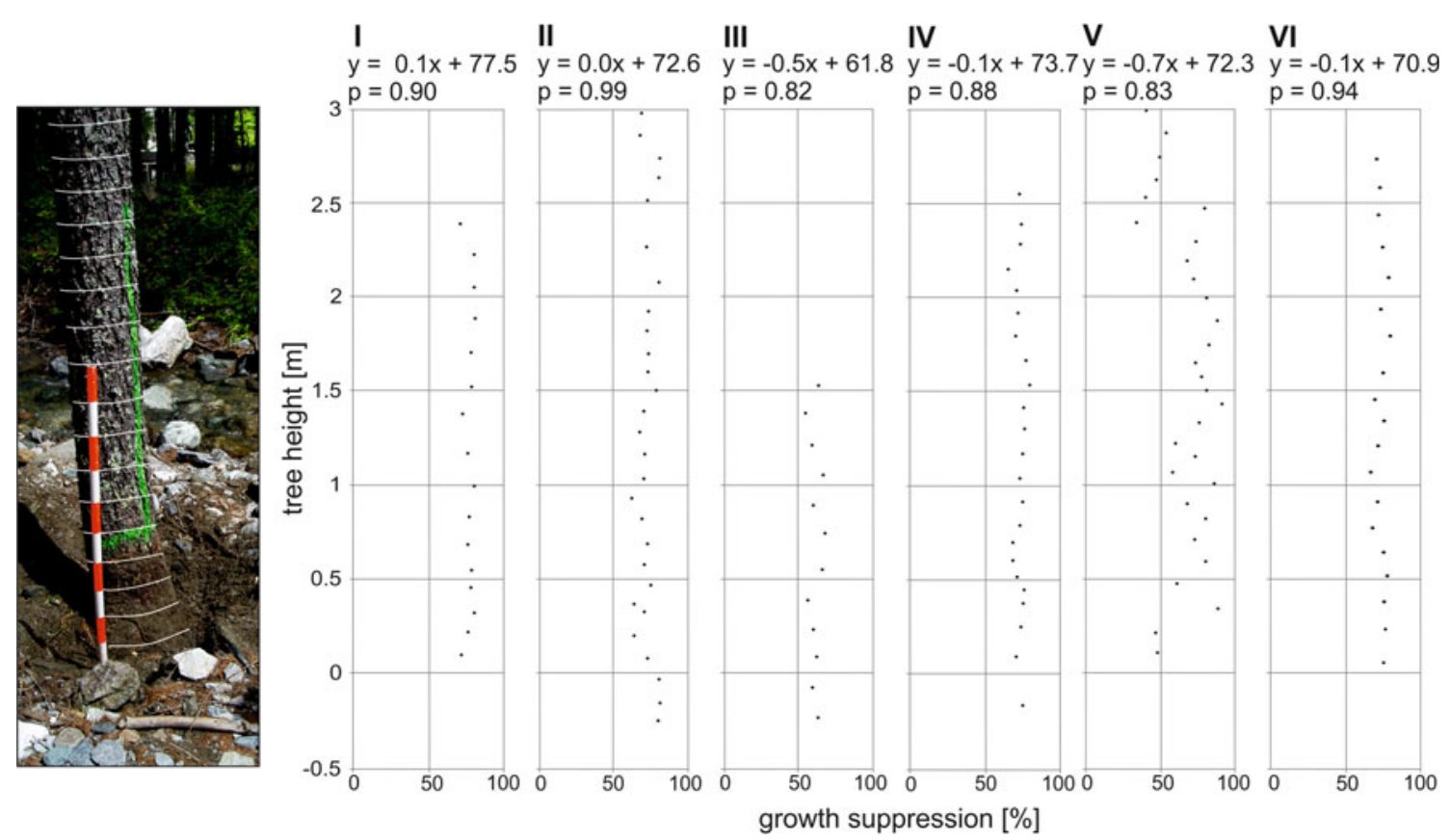

Fig. 4 Linear regression for the $\%$ of GR and tree height for trees $I, I I, I I I, I V, V, V I$. The $p$ value tests the claim that there is no relationship between tree height and the $\%$ of GS (significance level $p<0.05$ )

Fig. 1). An ANOVA test was applied to test whether growth suppression was significantly different on any of the sides. The results of the ANOVA test are presented in Table 2, showing that no significant differences exist in growth suppression between $a, b, c$, and $d$. The highest $p$ value was obtained for tree I with $p=0.5$ and lowest for tree $\mathrm{V}$ with $p=0.1$. In a similar way, the standard deviation was much higher in tree $\mathrm{V}$ than in any other of the trees sampled.

\section{Discussion}

In the study we report here, growth suppression was analyzed in 572 tree-ring series on 143 cross sections of six mature ( $46 \pm 8$ years) Larix decidua Mill. trees buried by $\sim 0.5 \mathrm{~m}$ of rocks and boulders contained in a sandy-silty matrix. The material was deposited under natural conditions by a debris flow in late 1979. This study is one in a few to report on growth suppression inflicted to adult trees under natural conditions and the first to quantitatively illustrate how burial affects increment growth in the axial and radial directions. The results illustrate quite clearly that the suppression in radial growth was severe for all trees and that ring width - as compared to the 1969-1979 control period-was reduced drastically following stem burial (mean $77 \%$, min $38 \%$, max $92 \%$, SD $7.2 \%$ ).

The analysis of suppression also showed that trees were unable to resume pre-burial growth rates even after
25 years, but that they recovered to reference growth conditions (as observed in undisturbed, local reference trees) after 15 years (min 3 years, max 25 years, SD 9 years) on average. Differences in the duration and severity of growth suppression in the sampled trees are likely reflective of differences in age at the moment of burial and/or different vitality. In the past, the recovery of growth rates following stem burial had often been attributed to the production of adventitious roots (Bégin et al. 1995; Dech and Maun 2006) or the re-exposure of stems due to subsequent erosive events (Marin and Filion 1992; Den Ouden et al. 2007). In our case, we observed neither adventitious roots nor had the trees been re-exposed by more recent debris flows; this is why, we consider growth recovery a natural reaction of $L$. decidua to stem burial, possibly through adaptation of the trunk and the stem base to the new situation. An experimental design for controlled environmental parameters could help to clarify the factors influencing the severity and length of the growth suppression.

Maximum growth suppression after burial was either observed in 1980 (trees II and IV) or 1981 (trees I, III, V, VI; also see Fig. 2), i.e., in the first and second year after burial, respectively. Signs of burial are clearly missing in the tree ring of 1979 , as the debris flow occurred after the completion of the corresponding ring. It is therefore likely that trees I, III, V, and VI benefitted from accumulated reserves first and thus only recorded the negative impacts of trunk burial in 1981. The results are therefore in concert 
Table 2 Differences in relative growth reductions (in \%) between the four sampling positions analyzed (see Fig. 1 for details) using an ANOVA test and a significance level of 0.05

\begin{tabular}{|c|c|c|c|c|}
\hline & & Sampling position & Mean & SD \\
\hline \multirow[t]{4}{*}{ I } & $p$ value $=0.50$ & a & 78.10 & 9.28 \\
\hline & & $\mathrm{b}$ & 73.50 & 7.51 \\
\hline & & c & 76.31 & 5.78 \\
\hline & & d & 74.61 & 5.74 \\
\hline \multirow[t]{4}{*}{ II } & $p$ value $=0.43$ & a & 73.93 & 7.77 \\
\hline & & $\mathrm{b}$ & 71.77 & 11.33 \\
\hline & & c & 74.07 & 7.68 \\
\hline & & d & 70.97 & 8.11 \\
\hline \multirow[t]{4}{*}{ III } & $p$ value $=0.13$ & $\mathrm{a}$ & 65.45 & 13.10 \\
\hline & & $\mathrm{b}$ & 61.42 & 10.25 \\
\hline & & $\mathrm{c}$ & 68.69 & 7.26 \\
\hline & & d & 57.14 & 9.32 \\
\hline \multirow[t]{4}{*}{ IV } & $p$ value $=0.12$ & a & 70.97 & 6.43 \\
\hline & & $\mathrm{b}$ & 75.77 & 5.24 \\
\hline & & $\mathrm{c}$ & 73.31 & 7.18 \\
\hline & & d & 74.09 & 6.76 \\
\hline \multirow[t]{4}{*}{ V } & $p$ value $=0.10$ & a & 72.29 & 19.61 \\
\hline & & $\mathrm{b}$ & 63.82 & 21.41 \\
\hline & & $\mathrm{c}$ & 67.75 & 24.56 \\
\hline & & d & 82.50 & 18.79 \\
\hline \multirow[t]{4}{*}{ VI } & $p$ value $=0.11$ & $\mathrm{a}$ & 71.64 & 5.73 \\
\hline & & $\mathrm{b}$ & 68.24 & 11.12 \\
\hline & & c & 73.60 & 8.05 \\
\hline & & d & 67.83 & 7.05 \\
\hline
\end{tabular}

STDEV standard deviation

with findings of the previous studies where the promptness of tree-ring reactions has been demonstrated to be strongly linked to tree species, vitality, velocity of the geomorphic event, and burial depth (Marin and Filion 1992; Cournoyer and Filion 1994; Kroprowski et al. 2010).

Interestingly, the results also show that little variation exists in growth suppression between different radial sampling positions $(a, b, c$, and $d$ ) as well as at different heights within the same tree. Tree $\mathrm{V}$ is exceptional in this respect and exhibits larger variations in growth suppression with whiskers identified at 27.9 and $94.6 \%$ for the 5 th and 95th percentiles, respectively. We believe that the high variation of growth suppression in tree $\mathrm{V}$ is partially reflective of its smaller DHB and much smaller increment where differences in widths between individual rings tend to be larger as compared to larger trees.

The axial distribution of growth suppression in the first year after burial did not vary significantly in our case, and thus with findings of Strunk (1997), who worked on stem burial of Picea abies (L.) Karst. by fine-grained dolomitic sediments. We assume that differences in results are due to the less dense matrix, lower load and the fertilizing effect of dolomitic sediments $\left(\mathrm{CaMg}\left(\mathrm{CO}_{3}\right)_{2}\right)$ on vegetation (Mayer et al. 2010). On the other hand, it is possible that smaller burial depths observed in their case might be yet another reason for varying and decreasing signals to burial due to the presence of a larger soil volume (Eldred and Maun 1982), increased mycorrhizal activity (Little and Maun 1996), and/or increased soil moisture (Maun 1998; Dech and Maun 2006), as reported in several studies (Alestalo 1971; Heikkinen and Tikkanen 1987; Filion and Marin 1988; Marin and Filion 1992; Strunk 1995; Mayer et al. 2010).

In contrast, the results of this study confirm findings in saplings where rapid and strong sand accumulation $(>0.6 \mathrm{~m})$ was shown to influence the same anatomical features expressed over the stem length (Matisons and Brümelis 2008; Kroprowski et al. 2010). Similar, the results of trees buried in experiments (Dech and Maun 2006) indicate that no significant difference of radial growth response exists in samples taken at the stem base $(0.3 \mathrm{~m})$ and at breast height $(1.3 \mathrm{~m})$. The systematic sampling of adult L. decidua to up to $3 \mathrm{~m}$ tree height in our study supports and expands these findings and shows that sudden and massive burial of mature trees influence radial growth of the entire stem.

This contribution is also the first to address the radial distribution of burial responses. Apparently, no significant differences exist in growth suppression between different sampling locations on a cross section, thus confirming the implicit statement of previous work according to which growth suppression can be followed throughout the stem. However, changes in wood formation (such as cell diameter, number and size of fibers) after burial on an anatomical level deserve attention and should be included in further analysis.

\section{Conclusions}

Growth response to stem burial resulting from aggradation of debris-flow material was investigated through the analysis of 572 growth series of Larix decidua Mill. Differences in the duration and severity of growth reduction are visible in the axial and radial directions, and presumably reflect differences in tree vitality and/or age trends. Growth suppression occurs with comparable levels of intensity throughout the stem and differences in treering response are not significant. Although this study revealed new and valuable insights into growth responses of L. decidua to stem burial, more research is clearly needed to fully decode and include more factors (e.g., age, burial depth) in future work addressing tree growth after aggradation events. 


\section{References}

Alestalo J (1971) Dendrochronological interpretation of geomorphic processes. Fennia 105:1-139

Bearth P (1973) Geologischer Atlas der Schweiz, Erläuterungen, 1:25’000, Blatt Simplon, Atlasblatt 61. Schweiz Geol Kommission

Bégin C, Michaud Y, Filion L (1995) Dynamics of a Holocene clifftop dune along Mountain River, Northwest Territories, Canada. Quat Res 44:392-404

Bollschweiler M, Stoffel M, Schneuwly DM, Bourqui K (2008) Traumatic resin ducts in Larix decidua stems impacted by debris flows. Tree Physiol 28:255-263

Cournoyer L, Filion L (1994) Variation in wood anatomy of white spruce in response to dune activity. Arct Antarct Alp Res $26: 412-417$

Day SD, Seiler JR, Kreh R, Smith DW (2001) Overlaying compacted or uncompacted construction fill has no negative impact on white oak and sweetgum growth and physiology. Can J For Res 31:100-109

Dech JP (2004) The ecological significance of sand burial to woody plants on coastal sand dunes. Dissertation, University of Western Ontario

Dech JP, Maun MA (2006) Adventitious root production and plastic resource allocation to biomass determine burial tolerance in woody plants from central Canadian coastal dunes. Ann Bot 98:1095-1105

Den Ouden J, Sass-Klaassen UGW, Copini P (2007) Dendrogeomorphology - a new tool to study drift-sand dynamics. Neth J Geosci 86:355-363

Eldred RA, Maun MA (1982) A multivariate approach to the problem of decline in vigour of Ammophila. Can J Bot 60:1371-1380

Filion L, Marin P (1988) Modifications morphologiques de l'épinette blanche sourmise à la sedimentation éolienne en milieu dunaire, Québec subarctique. Can J Bot 66:1862-1869

Friedman J, Vincent KR, Shafroth PB (2005) Dating floodplain sediments using tree-ring response to burial. Earth Surf Process Landf 30:1077-1091

Heikkinen O, Tikkanen M (1987) Thekalajoki dune field on the west coast of Finland. Fennia 165:241-267

Hupp CR (1988) Plant ecological aspect of flood geomorphology and paleoflood history. In: Baker VR, Kochel RC, Patton PC (eds) Flood geomorphology. Wiley, New York, pp 335-356

Jury WA, Horton R (2004) Soil physics. Wiley, Oxford, p 384

Kent M, Owen NW, Dale P, Newham RM, Giles TM (2001) Studies of vegetation burial: a focus for biogeography and biogeomorphology? Prog Phys Geog 25:455-482

Kny L (1877) Das Dickenwachstum des Holzkörpers an beblätterten Sprossen und Wurzeln und seine Abhängigkeit von äußeren Einflüssen, insbesondere von Schwerkraft und Druck. Bot Z $35: 415-466$

Kroprowski M, Winchester V, Zielski A (2010) Tree reactions and dune movemtns: Slowinski National Parks, Poland. Catena 81:55-65

Little LR, Maun MA (1996) The 'Ammophila' problem revisited: arole for mycorrhizal fungi. J Ecol 53:447-463

Liu B, Fujita T, Yan ZH, Sakamoto S, Xu D, Abe J (2007) QTL mapping of domestication related traits in soybean (Glycine $\max$ ). Ann Bot 100:1027-1038

Marin P, Filion L (1992) Recent dynamics of subarctic dunes ad determined by tree-ring analysis of white spruce, Hudson Bay, Quebec. Quat Res 38:316-330

Matisons R, Brümelis G (2008) Effects of burial by sand on Scots pine (Pinus sylvestrisL.) radial growth on seacoast wooded dunes at Cape Kolka, Latvia. Acta Univ Latv 745:131-144
Maun MA (1998) Adaptations of plants to burial in coastal sand dunes. Can J Bot 76:713-738

Maun MA (2004) Adaptiations of plants to burial in coastal sand dunes. Can J Bot 76:713-738

Mayer B, Stoffel M, Bollschweiler M, Hübl J, Rudolf-Miklau F (2010) Frequency and spread of debris floods on fans: a dendrogeomorphic case study from a dolomite catchment in the Austrian Alps. Geomorphology 118:199-206

MeteoSwiss (2008) Federal Office of Meteorology and Climatology, MeteoSwiss. http://www.meteo-schweiz.ch

Müller HN (1980) Angewandte Pflanzensoziologie; Jahrringwachstum und Klimafaktoren, Österreichischer Agrarverlag, Wien, Heft 25

Nanson GC, Beach HF (1977) Forest succession and sedimentation on a meandering-river floodplain, northeast British Columbia. Can J Biogeogr 4:229-251

Rinntech (2011) LINTAB_Präzision-Jahrring für Jahrring. http:// www.rinntech.com/content/view/16/47/lang,german. Accessed 10 Oct 2011

Rubner K (1919) Das Hungern des Cambiums und das Aussetzen der Jahrringe. Naturwiss Z Fors-Landwirtsch 8:212-262

Rubtsov MV, Salmina IUN (1983) Use of buried Salix thickets for determination of the chronology of floodplain deposits. Lesovedenie 5:69-70

Shi L, Zhang ZF, Zhang CY, Zhang JZ (2004) Effects of sand burial on survival, growth, gas exchange and biomass allocation of Ulmus pumilla seedlings in the Hunshandak Sandland, China. Ann Bot 94:553-560

Shroder JF (1978) Dendrogeomorphological analysis of mass movement on Table Cliff Plateau, Utah. Quat Res 9:168-185

Singh G, Rathod TR (2002) Plant growth, biomass production and soil water dynamics in a shifting dune of Indian desert. For Ecol Manage 171:309-321

Stoffel M, Bollschweiler M (2008) Tree-ring analysis in natural hazards research-an overview. Nat Hazard Earth Sys Sci 8:187-202

Stoffel M, Bollschweiler M (2009) What tree rings can tell about earth-surface processes: teaching the principles of dendrogeomorphology. Geogr Compass 3:113-137

Stoffel M, Lièvre I, Conus D, Grichting MA, Raetzo H, Gärtner HW, Monbaron M (2005) 400 years of debris flow activity and triggering weather conditions: Ritigraben VS, Switzerland. Arctic Antarc Alp Res 37:387-395

Stoffel M, Conus D, Grichting MA, Lièvre I, Maître G (2008) Unraveling the patterns of late Holocene debris-flow activity on a cone in the central Swiss Alps: chronology, environment and implications for the future. Glob Planet Change 60:222-234

Stoffel M, Corona C, Ballesteros Canovas JA, Bodoque del Pozo JM (in press) Dating and quantification of erosion processes using exposed roots. Earth Sci Rev

Strunk H (1991) Frequency distribution of debris flows in the Alps since the "Little Ice Age". Zeitschrift für Geomorphologie 83:71-81

Strunk H (1995) Dendrogeomorphologische Methoden zur Ermittlung der Murfrequenz und Beispiele ihrer Anwendung. Roderer Verlag, Regensburg

Strunk H (1997) Dating of geomophological processes using dendrogeomrphological methods. Catena 31:137-151

Yoshihika AM, Hukusima T (1997) The impact of extreme runoff events from the Sakasagawa river on the Senjogahra ecosystem, Nikko National Park V. The importance of adventitious root systems for the burial tolerance of different tree species. Ecol Res 12:39-46

Zhang J, Maun MA (1990) Effects of sand burial on seed germination, seedling emergence, survival, and growth of Agropyron psammophilum. Can J Bot 68:304-310

Zhao WZ, LI QY, Fang HY (2007) Effects of sand burial on seedling growth of Nitrariasphaerocarpa. Plant Soil 295:95-102 